\title{
EKSPEKTASI DAN PERSEPSI WISATAWAN TERHADAP KUALITAS PELAYANAN PADA MARINA SRIKANDI TOUR \& TRAVEL DI PADANGBAI
}

\author{
Made Natha Dwipayana \\ I Ketut Suwena \\ Yayu Indrawati \\ Email: madenathadwipayana@ymail.com \\ PS. S1 Industri Perjalanan Wisata \\ Fakultas Pariwisata UNUD
}

\begin{abstract}
Differences between expectation and perception of visitor about service quality of a travel agency were the background of this research which is entitled "Visitor's Perception And Expectation of Service Quality At Marina Srikandi Tour And Travel In Padang Bai. Through this research, a thought to maintain professionalism of travel agency with qualified standards, understand different visitor expectations was a major thing that want to be achieved. Background of problem in this research was divided into two problems, such as (1) what are visitor expectation and perception about service quality at Marina Srikandi Tour and travel? (2) How is the visitor's satisfaction about service quality which is given by Marina Srikandi Tour and travel? Based on the background of problems above, there were two aims of study in this research, they are: (1) to know visitor expectation and perception about service quality at Marina Srikandi Tour and travel, and (2) to know visitor's satisfaction about service quality which is given by Marina Srikandi Tour and travel.
\end{abstract}

Keywords: Expectation, Perception, Service of Quality.

\section{PENDAHULUAN}

Bali merupakan pulau yang memiliki keragaman budaya, adat istiadat, iklim, serta alam antara daerah satu dengan yang lainnya yang menjadikan Bali sebagai pulau yang memiliki potensi untuk dikembangkan menjadi daerah tujuan wisata. Salah satu upaya yang dilakukan pemerintah untuk mewujudkan pariwisata sebagai sektor andalan yakni dengan cara membangun sarana dan prasarana penunjang di daerah tujuan wisata. Keragaman kebudayaan, adat istiadat, keindahan alam, keramahtamahan penduduknya serta sarana dan prasarana pendukung yang telah dibangun merupakan unsur pengembangan pariwisata itu sendiri.

Bali sebagai daerah tujuan wisata mempunyai banyak potensi wisata yang terus berkembang. Salah satu potensi pariwisata yang menjadi penunjang kepariwisataan antara lain: atraksi wisata, produk-produk kerajinan tangan, kesenian, dan masih banyak lagi usaha-usaha lainnya yang seluruhnya bertujuan untuk meningkatkan arus kunjungan wisatawan ke Bali.

Bali terdiri dari beberapa kabupaten, salah satunya adalah Kabupaten Karangasem. Kabupaten Karangasem adalah kabupaten yang terletak di wilayah timur provinsi Bali, Indonesia. Ibu kotanya berada di Amlapura. Karangasem terkenal dengan keindahan alam baik pengunungan, wisata dasar lautnya, dan adat istiadat yang beranekaragam. Keindahan alam, peninggalan sejarah, serta adat istiadat yang beragam menyebabkan banyak wisatawan yang datang dan berkunjung ke daerah Karangasem. Oleh karena itu beberapa travel agent membuat paket tour ke daerah ini dan menawarkan pelayanan serta kenyamanan yang dibutuhkan oleh wisatawan saat melakukan tour.

Salah satu travel agent yang menawarkan pelayanan dan kenyamanan bagi wisatawan adalah Marina Srikandi Tour \& 
Travel yang terletak di Padangbai. Perusahaan ini merupakan salah satu travel agent yang bergerak dalam bidang jasa yang mengedepankan kepuasan pelanggan. Dalam menciptakan kepuasan pelanggan maka diperlukan pelayanan yang baik, hal inilah yang menjadi tolak ukur bagi Marina Srikandi Tour \& Travel dalam menjalankan usahanya di bidang jasa perjalanan. Dari hal tersebut maka perlu dilakukan penelitian mengenai ekspektasi dan persepsi wisatawan terhadap kualitas pelayanan pada travel ini, untuk mengetahui bagaimana ekspektasi dan persepsi wisatawan terhadap pelayanan yang diberikan dan indikator apa saja yang perlu dibenahi dalam meningkatkan kualitas pelayanan pada Marina Srikandi Tour \& Travel.

\section{TINJAUAN PUSTAKA}

Menurut Muljadi (2009 : 124), Travel Agent adalah perusahaan yang mengurus perjalanan seseorang atau sekelompok orang dengan menghubungkan antara perusahaan yang menyediakan fasilitas perjalanan yang dibutuhkan dengan orang yang akan mengadakan perjalanan dan menjalankan fungsi "keagenan" atau perantara, jadi travel agent tidak memiliki produk, tapi menjual produk usaha lain misalnya Hotel, Restoran, Penerbangan, Paket Wisata dll.

Menurut Kotler (2002: 83) definisi pelayanan adalah setiap tindakan atau kegiatan yang dapat ditawarkan oleh suatu pihak kepada pihak lain, yang pada dasarnya tidak berwujud dan tidak mengakibatkan kepemilikan apapun. Pelayanan merupakan perilaku produsen dalam rangka memenuhi kebutuhan dan keinginan konsumen demi tercapainya kepuasan pada konsumen itu sendiri.

Menurut Zethaml et al. (1993) yang dikutip oleh Tjiptono dan Chandra (2004: 122) menyatakan bahwa harapan/ekspektasi merupakan keyakinan pelanggan sebelum mencoba atau membeli suatu produk, yang dijadikan standar atau acuan dalam menilai kinerja produk bersangkutan. Sementara itu menurut Shaleh (2009 : 110), persepsi adalah suatu proses yang menggabungkan dan mengorganisir data-data indera kita (penginderaan) untuk dikembangkan sedemikian rupa sehingga kita dapat menyadari di sekeliling kita, termasuk sadar akan diri kita sendiri.

\section{METODE PENELITIAN}

Penelitian ini dilakukan di Marina Srikandi Tour \& Travel yang berlokasi di desa Padangbai, Kecamatan Manggis, Kabupaten Karangasem, Provinsi Bali. Jumlah responden dalam penelitian ini sebanyak 45 orang dengan sistem Accidental Sampling. Analisis data dalam penelitian ini menggunakan analisis data kuantitatif dan kualitatif yang dipadukan dengan skala likert untuk mengolah data hasil penyebaran kuesioner yang sudah diisi oleh wisatawan.

\section{HASIL DAN PEMBAHASAN}

Berdasarkan penelitian persebaran kuesioner yang dilakukan, kepada wisatawan yang menggunakan jasa Marina Srikandi Tour \& Travel tentang karakteristik wisatawan diperoleh hasil yaitu wisatawan yang memanfaatkan jasa tour \& travel ini didominasi oleh wisatawan mancanegara dengan persentase sebesar 38\%. Rata-rata tingkat usia yang paling banyak menggunakan jasa travel ini berkisar antara 21-30 tahun dengan persentase sebesar 55\%, karena kesehatan fisik wisatawan dengan usia tersebut lebih memungkinkan melakukan perjalanan wisata dibandingkan dengan usia di atas 30 tahun.

Menurut hasil penyebaran kuesioner mengenai ekspektasi wisatawan domestik maupun mancanegara terhadap kualitas pelayanan dalam menangani wisatawan diperoleh skor rata-rata keseluruhan sebesar 3,44 atau dapat dikatatakan harapan dari wisatawan sangat baik, karena setiap wisatawan mengharapkan kualitas pelayanan yang sangat baik saat menggunakan jasa travel ini.

Berdasarkan hasil penyebaran kuesioner mengenai persepsi wisatawan domestik maupun mancanegara terhadap kualitas pelayanan dalam menangani wisatawan diperoleh skor rata-rata keseluruhan sebesar 2,0 atau dapat dikatakan persepsi dari wisatawan cukup baik, ini dikarenakan kualitas pelayanan yang dirasakan wisatawan belum dapat memuaskan dari harapan wisatawan tersebut. 
Selanjutnya berdasarkan hasil penelitian mengenai kepuasan wisatawan yang menggunakan jasa Marina Srikandi Tour \& Travel yaitu diperoleh skor rata-rata 3,44 untuk harapan dari wisatawan dan mendapatkan skor rata-rata 2,0 untuk persepsi dari wisatawan atau dapat dikatakan wisatawan merasa tidak puas dengan pelayanan yang diberikan. Untuk hasil analisis diagram cartesius dapat dilihat pada Gambar 1.

Gambar 1. Diagram Kartesius

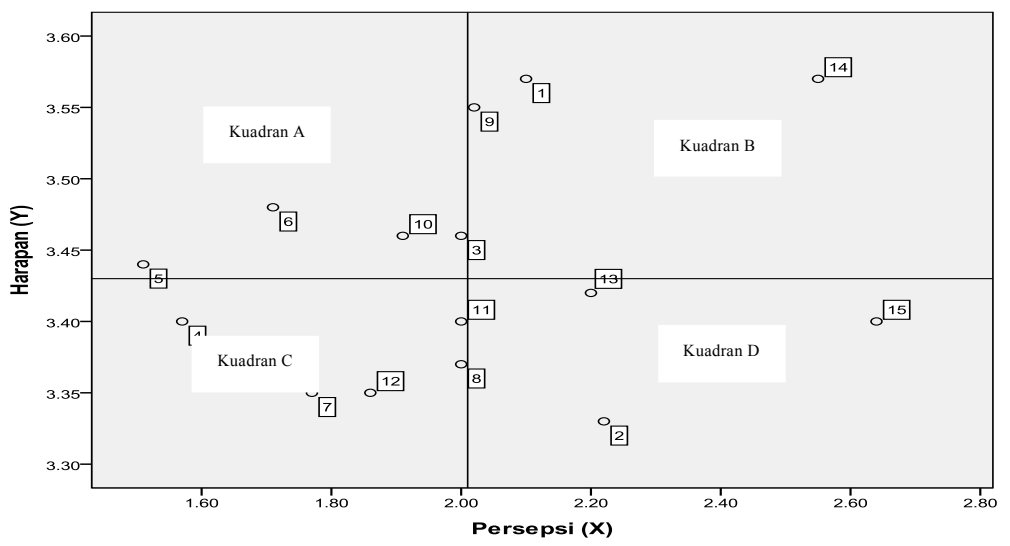

Keterangan : (1) ketepatan waktu saat berangkat dan tiba di lokasi tujuan, (2) ketepatan karyawan dalam menangani checkin di counter, (3) memberikan pelayanan seperti yang dijanjikan kepada wisatawan, (4) kemampuan karyawan dalam menindak lanjuti keluhan wisatawan, (5) kecepatan dalam menanggapi keluhan wisatawan, (6) pelayanan pada jam kerja yang lebih panjang, (7) dapat meyakinkan wisatawan bahwa kebutuhannya akan ditangani dengan baik, (8) rasa aman yang diberikan oleh pengendara, (9) pelayanan yang ramah dan sopan, (10) keramahtamahan karyawan saat berkomunikasi dengan wisatawan, (11) perhatian khusus \& penciptaan hubungan baik dengan wisatawan, (12) kesediaan karyawan dalam memberikan informasi yang dibutuhkan wisatawan, (13) penampilan karyawan dalam melayani wisatawan, (14) kebersihan transportasi yang digunakan wisatawan, (15) fasilitas fisik yang ada di dalam transportasi yang anda gunakan.

Kuadran A (prioritas utama) menunjukan, bahwa kualitas pelayanan yang sangat diharapkan oleh wisatawan, akan tetapi pihak pengelola yaitu Marina Srikandi Tour \& Travel belum melaksanakan sesuai dengan keinginan wisatawan sehingga menimbulkan rasa tidak puas. Adapun indikator-indikator pada kuadran ini antara lain: memberikan pelayanan seperti yang dijanjikan kepada wisatawan, kecepatan karyawan dalam menanggapi keluhan wisatawan, pelayanan pada jam kerja yang lebih panjang, dan keramahtamahan karyawan saat berkomunikasi dengan wisatawan. Lalu Kuadran B (dipertahankan) menunjukan bahwa kualitas pelayanan yang di harapkan oleh wisatawan telah dilaksanakan dengan baik dan dapat memuaskan wisatawan, sehingga pihak pengelola hanya perlu mempertahankan kinerjanya. Adapun indikator-indikator pada kuadran ini antara lain: ketepatan waktu saat berangkat dan tiba di lokasi tujuan, pelayanan yang ramah dan sopan, kebersihan transportasi yang digunakan wisatawan. Sementara Kuadran C (prioritas rendah) menunjukan bahwa pelayanan yang diberikan kurang penting pengaruhnya bagi wisatawan, dimana pelaksanaannya oleh pihak pengelola dianggap kurang penting, namun ini menyebabkan wisatawan merasa tidak puas dengan kinerja pengelola. Adapun indikator-indikator pada kuadran ini antara lain: kemampuan karyawan dalam menindak lanjuti keluhan wisatawan, dapat meyakinkan wisatawan bahwa kebutuhannya akan ditangani dengan baik, rasa aman yang diberikan oleh pengendara, perhatian khusus dan penciptaan hubungan baik dengan dengan wisatawan. kesediaan karyawan dalam memberikan informasi yang dibutuhkan wisatawan. Kuadran D (berlebihan) menunjukan bahwa pelayanan 
yang kurang diharapkan, tapi telah dijalankan dengan baik oleh pihak pengelola dan sangat memuaskan bagi wisatawan. Adapun indikator-indikator pada kuadran ini adalah: ketepatan karyawan dalam menangani checkin di counter, penampilan karyawan dalam melayani wisatawan, fasilitas fisik yang ada di dalam transportasi yang digunakan.

\section{SIMPULAN DAN SARAN Simpulan}

Berdasarkan pembahasan mengenai ekspektasi dan persepsi wisatawan terhadap kualitas pelayanan pada Marina Srikandi Tour \& Travel dapat diambil beberapa kesimpulan sebagai berikut:

1. Ekspektasi wisatawan yang menggunakan jasa Marina Srikandi Tour \& Travel mendapat rata-rata $3,44 \%$ atau dikategorikan sangat baik, dalam hal ini wisatawan mengharapkan kualitas pelayanan yang memuaskan.

2. Persepsi wisatawan yang menggunakan jasa Marina Srikandi Tour \& Travel mendapat rata-rata $2,0 \%$ atau dikategorikan cukup baik atau pelayanan yang dirasakan jauh dari harapannya.

3. Tingkat kepuasan wisatawan yang menggunakan jasa Marina Srikandi Tour \& Travel dapat dilihat dari pelayanan yang diberikan kepada wisatawan. Berdasarkan ekspektasi wisatawan dengan skor ratarata $3,44 \%$ atau dikategorikan sangat baik dan persepsi wisatawan dengan skor ratarata $2,0 \%$ atau dikategorikan cukup baik, tingkat kepuasan terhadap kualitas pelayanan yang diterima wisatawan dapat dikatakan wisatawan merasa kecewa atau tidak puas.

\section{Saran}

Selanjutnya berdasarkan simpulan tersebut dapat dapat disarankan yaitu: hendaknya pihak Marina Srikandi Tour \& Travel meningkatkan kualitas pelayanan yang diberikan kepada wisatawan, agar pelayanan yang diharapkan wisatawan dapat memenuhi keinginan wisatawan sebelum menggunakan jasa travel ini.

\section{DAFTAR PUSTAKA}

A.J, Muljadi. 2009. Kepariwisataan dan Perjalanan. Jakarta: Rajawali Pers.

Kotler, Philip. 2002. Manajemen Pemasaran di Indonesia : Analisis, Perencanaan, Implementasi dan Pengendalian. Salemba Empat. Jakarta.

Shaleh, Abdul Rahman. 2009. Psikologi Suatu Pengantar Dalam Perspektif Islam. Jakarta: Kencana

Tjiptono, Fandi dan Gregorius Chandra. (2004) Service, Quality dan Satisfaction. Penerbit Andi. Yogyakarta.

Yoeti, Oka A. 1993. Pengantar Ilmu Pariwisata. Bandung : Angkasa. 